zones on the film.

(4) Other spots are indexed by a trial-and-error search of interplanar angles within each zone separately, with the indexed spots from (3) as starting points.

The use of short programs (Iess than 2560 words each) and extensive data files minimizes core requirements so that the programs could be used with a laboratory microcomputer with aporopriate disc storage. Over 25 spots on each of several dozen laue photographs of calcite (trigonal) have been successfully indexed. In addition, the programs have been checked with Ploc's data for $a-2 r$ (hexagonal) with identical results, and with computer plots of indexed back-reflection. patterns of $\mathrm{Cu}$ (cubic), B-Sn (tetragonal), $\mathrm{Ga}$ forthohombic), and $\alpha-P_{u}$ (monoclinic, also as "triclinic") from Preuss et al. (Laue Atlas, N. Y., Wiley and Sons, 1974). Coordinates of $11-15$ intense reflections from each of the computer plots were entered as "data," and the published Miller indices were all correctly redetermined. Maximun Miller and zone indices of 20 and 8 , respectively, have teen found in calcite. Average interplanar and interaxial angular errors are about $0.1^{\circ}$ for carefully read and calibrated films or about $0.5^{\circ}$ for the published computer plots. Over 30 spots on a single film can be unambiguously indexed by a person with minimal crystallographic experience using these programs.

18.1-02 IDENTIFICATTON OF THE METRIC SYMMETRY OF A LATTICE BY FINDING ITS EVEN-ORDER SYMMETRY AXES By $\underline{Y}$. Le Page, Chemistry Division, M12-BG. NRC, OTTAWA, CANADA, KIA ORg

The present approach is based on the identification of even-order symmetry axes (EOSA) according to the following three points: (1) A row [h] is an EOSA of a lattice if and only if there is a reciprocal row [p*] such that $h \times \mathrm{p}^{*}=0$ with $\mathrm{h}$. $\mathrm{p}^{*}=1$ or 2 ; (2) If the lattice is referred to its 3 shortest non-coplanar translations, the moduli of the Miller indices of [h] and $\left[p^{*}\right]$ cannot be larger than 2 ; (3). A lattice symetry is uniquely determined by the number and distribution in space of its EOSA.

The first two points allow an exhaustive. list of the EOSA in the lattice to be made. Comparison of the number and distribution of EOSA in space with those possible allows the lattice symmetry to be identified according to point 3. By this process, the lattice is placed in a conventional orientation and the selection of the edges of the conventional cell is guided by the coincidence of lattice rows with pre-determined symetry axes.

Some advantages over the traditional approach sumarized in International Tables (1969) Vol. 1 pp. 530-535 are: The recognition of the lattice symetry can be accomplished by one logical process rather than 44 branches; seudo symmetry in the primitive cell can be liandled in a straightforward way; A Buerger reduced cell rather than the Niggli reduced cell is required; No metric considerations are built into the recognition of the lattice symmetry. Metric conventions in orthorhombic, monoclinic and triclinic are handled separately.

The program tuns on PDP8-E, PDP11 and CDC 7400 computers and has been inserted as an overlay in the NRC Fortran diffractometer program.
18.1-03

\section{INTELLIGENCE ARTIFICIELLE ET} MESURE DE PIC

par

M. Tournarie

DphG-PSRM, CEA, B.P.n०2, $91191 \mathrm{Gi}$ sur Yvette, France

On sait ${ }^{[1]}$ que chaque observation permet l'affinement imédiat de toutes les variables descriptives du phénomène physique qui lui a donné naissance. Cette remarque conduit à la construction d'un algorithme genera1[3] permettant à la fois le traitement des données experimentales et le choix des conditions d'acquisition suboptimales. I'emploi de cet algorithme évite de consacrer beaucoup de temps aux observations peu efficaces.

Pour optimiser il faut définir un critère qu'on cherchera à rendre extrêmal. Le critère choisi est le gain d'information apporte par chaque observation sur une combinaison tinéaire des inconnues. On aboutit alors à l'algorithme suivant.

Ayant choisi la combinaison linéaire $\langle c \mid x\rangle$ dont on veut optimiser la mesure ayant les valeurs $\mid z>$ a priori de $|x\rangle$ et la matrice d'erreur $E$ relative à ces estimations.

$1^{\circ}$ ) Pour chaque observation possible a) calculer son espérance a et l'espérance de son vecteur gradient a par rapport aux inconnues estimees $a=\operatorname{Esp}(y \| z>)$

b) calculer pour le temps d'observation t la quanti-

$$
Y=\frac{T}{q a+\tau<a|E| a>} q \text { : quantum unité }
$$

c) determiner l'observation qui fait décroitre le plus vite l'écart type sur $\langle c \mid x\rangle:$ c'est l'observation qui présente le $\langle c|E| c\rangle u=\gamma\langle c|E| a\rangle^{2}$ maximum.

$2^{\circ}$ ) Effectuer cette observation.

$\left.3^{\circ}\right)$ Calculer les notvelles estimations $|z\rangle$ des inconnues et leur matrice d'erreur $E$ selon la formule de Iéestimation linéaire [1].

$$
\begin{aligned}
& \left.|z>+| z>+\frac{\mathrm{y}-\mathrm{a}}{\mathrm{q} a+\mathrm{I}\langle\mathrm{a}|\mathrm{E}| \mathrm{a}\rangle}|\mathrm{E}| \mathrm{a}\right\rangle \\
& \mathrm{E}+\mathrm{E}-\frac{\mathrm{I}}{\mathrm{qa}+\mathrm{\tau}\langle\mathrm{a}|\mathrm{z}| \mathrm{a}\rangle} \mathrm{E}|\mathrm{a}\rangle\langle\mathrm{a}|\mathrm{E}|
\end{aligned}
$$

$\left.4^{\circ}\right)$ Si la variation de $|z\rangle$ est déraisonnable ou aboutit à des valeurs de $|z\rangle$ déraisonnables, effectuer une réestimation non linéaire des inconnues [2]

$\left.5^{\circ}\right)$ Si la précision obtenue n'est pas suffisante et si la durée totale acceptée pour l'ensemble des observations n'est pas épuisée revenir en $1^{\circ}$ )

$\left.6^{\circ}\right)$ Fin

Une application à la recherche, la détermination et l'affinement des caractéristiques (intensite, position, largeur, dissymétrie) de pic est présentée.

1 TOURNARIE M. (1969), Ann. Inst. H. Poincare 5 , $\mathrm{n}^{\circ} 1, \mathrm{~B}, 49-67$

2 TOURNARIE $M$. (1969) J. Physique 30, $\mathrm{N}^{\circ} 10,737-751$

3 TOURNARIE M. (1978), Cybemetica XXI, 3, 227-262 